\title{
Biosecurity of Poultry Worker Related to Avian Influenza in Bangladesh
}

\author{
Swapan Kumar Roy, Quazi Zahangir Hossain \\ Research Fellow, Department of Public Health, Northern University Bangladesh, Bangladesh
}

\begin{tabular}{l} 
Article Info \\
\hline Article history: \\
Received Oct 27, 2014 \\
Revised Nov 20, 2014 \\
Accepted Nov 25, 2014 \\
\hline Keyword: \\
Avian influenza \\
Biosecurity \\
Live bird market \\
Personal protective equipment \\
Poultry worker
\end{tabular}

\section{Article Info}

\section{Keyword:}

Biosecurity

Personal protective equipment

\begin{abstract}
Research on biosecurity of poultry workers of Live Bird Market (LBM) in urban and rural areas related to highly pathogenic avian influenza (AI) was undertaken during March-June, 2014 at Keshabpur upazila $\left(22^{\circ} 48^{\prime}-22^{\circ} 57^{\prime} \mathrm{N}\right.$ latitude and $89^{\circ} 06^{\prime}-89^{\circ} 22^{\prime} \mathrm{E}$ longitude), Jessore, Bangladesh. A nonrandomized (purposive) sampling method was applied and a descriptive type of cross sectional study was performed among 72 workers, dividing them into two groups as 36 urban and 36 rural poultry workers of LBM through split-halves variation technique. They were interviewed confidentially in their work place using a structured pretested questionnaire. Among respondents $53 \%, 75 \%, 45 \%, 81 \%$, and $56 \%$ of urban and $50 \%, 42 \%, 50 \%$, $89 \%$, and $36 \%$ of rural residence had attended up to primary school, knowledge about AI through media like TV and radio, used proper personal protective equipment as mask and gloves, washed their hands and equipment after finishing work and cleaned stalls/cages daily and mostly they used water as a cleaning material, respectively. In urban $(14 \%)$ and rural $(36 \%)$ workers used the same vehicle to transport poultry and humans. A combined effort is required to enhance knowledge and change behavior among those most at risk in low-income countries and precautions necessary to avoid spreading the virus among poultry and humans.
\end{abstract}

Copyright (C) 2014 Institute of Advanced Engineering and Science. All rights reserved.

\section{Corresponding Author:}

Swapan Kumar Roy

Department of Public Health, Northern University Bangladesh, 41/42 Mazid Sarani, Shibbari Circle, Khulna, Bangladesh.

Email: sawpan_69@yahoo.com

\section{INTRODUCTION}

Avian Influenza as an emerging infectious disease of birds caused by influenza virus type A [1], commonly known as bird flu. Avian influenza a virus subtype H5N1 has caused many human fatalities and continues to pose an increasing pandemic threat [2], [3]. The world threat by avian influenza virus's need to awareness, knowledge, and readiness to outbreak and biosecuritry practices in Kogi State, Nigeria is studied revealed that high level of awareness and readiness to outbreak Highly Pathogenic Avian Influenza (HPAI) but poor knowledge and biosecurity practices towards it [4]. Live bird market workers in Mymensingh, Bangladesh [5], Zakarta, Indonesia [6] and in Lagelu, Oyo State, Nigeria [7] were conducted on knowledge, attitudes and practices/compliance (KAP). Study on origin and evolution of HPAI in Asia revealed that approaches to control of H5N1 have been developed through observations and experiences [8]. Traditional Asian wet markets provide major contact points for people and live animal mixing, making them important potential sources of viral amplification and infection [9]. Avian influenza viruses in Korean live poultry markets and their pathogenic potential study explored that mode of selling birds varies in different localities are adopted according to demand [10]. Research towards control of H5N1 was undertaken like human infection and to reduce the risk of zoonotic transmission of the virus, prevent secondary cases and provide 
baseline comparison for the early detection of changes in virus transmissibility in Indonesia [11]. Cleaning and disinfection method of poultry farms that awareness of avian influenza on signs, symptoms and preventive measures was prescribed [12]. A high risk of public health problems due to HPAI and there is no effective enforcement of the local HPAI control regulation in Jakarta city on the poultry collection sites and traditional slaughter houses that continue to conduct unsafe practices of poultry slaughter [13]. In Hong Kong after flu outbreak explored that feathers, feces, as well as, blood and intestines soiled and contaminates the markets which help in spreading the virus into the markets [14]. Workers in the poultry industry, who commonly have contact with live, sick, or dying poultry, are at high risk for avian influenza [15]. The 'classical' approach to HPAI control and elimination based on early detection and stamping out has proved to be effective in most cases for elimination of HPAI and some LPAI viruses from the British Columbia commercial poultry industry [16]. Avian influenza and human health study opined that the world is now under human pandemic threat by avian influenza viruses [17].

In Bangladesh significant numbers of people in both urban and rural areas are completely dependent on live bird marketing. The interactions of humans with poultry in these settings provide risk of exposure to virus. The likelihood of transmission risk to human populations is unknown and needs to be assessed and scanty work had been done in Bangladesh. Therefore, the research has been conducted to obtain an understanding on biosecurity of workers in urban and rural live bird markets related to highly pathogenic avian influenza at Keshabpur upazila, Jessore.

\section{RESEARCH METHOD}

A descriptive type of cross-sectional study was conducted from March-June, 2014 at Keshabpur upazila under Jessore district. Data collection tools were the questionnaire survey and the technique of data collection among 72 poultry workers each halve from urban and rural areas was confidentially interviewed face to face in their workplace. The respondents were asked general information, knowledge of transmission and prevention of avian influenza, attitudes and practices toward the disease, precautions at work, sources of information, pattern of selling birds and cleanliness. Sample completed the questionnaire using about 30 minutes to complete the scale. Statistical analysis was done by SPSS (version 16.0).

\section{Measures} follows:

Data were collected using a structured pretested questionnaire. The questionnaire was composed as

General information variables were age, sex, education level, working experience and location of business. Knowledge related variable were idea about flu in humans/poultry, type of flu, knowledge about highly pathogenic avian influenza (HPAI), transmission of HPAI (from bird to human body), sources of infection of the target groups and protective measures for reducing the risk of transmitting HPAI.

Attitude related variables were fundamental attitudes and beliefs, misconceptions of the statements related to HPAI.

Practice related variables were selling of live birds (number), waste management from poultry business, average time of remaining birds in the stall and practices on selling of sick birds.

\section{Validity and reliability of questionnaire}

Before using the questionnaire, it had been tested with 10 pilot samples of poultry workers from Live Bird Market of Monirampur upazila of Jessore district and measured subjectively by the researcher. The validity was measured based on researcher judgment whether all of the pilot samples were understood and provided the appropriate answers to the questions. The reliability was measured based on judgment whether all of the pilot sample results were consistent.

\section{Statistical analysis}

Cross tabulations were calculated to evaluate the influence of independent variables like education level, working experience and location of business on different dependent variable like knowledge about HPAI, transmission of avian influenza among poultry and humans, yearly income, using proper personal protective equipment (PPE), cleaning the stalls/cages daily, using the same vehicles to transport poultry and humans, waste management from poultry business, keeping adequate water nearby stalls, annual health check of LBM workers and if the workers became infected whether reported to it public health authority etc. with 
95\% confidence intervals. The statistical analyses were performed using SPSS (version 16.0), with significance level of $\mathrm{P}<0.05$.

\section{RESULTS AND ANALYSIS}

\subsection{Statistical analysis}

Among the respondents $53 \%$, and $42 \%$ of urban and $50 \%$, and $31 \%$ of rural LBM workers were up to primary school and secondary school, respectively. Significant relationships between education level and waste management from poultry business showed that Chi-square 20.228, $\mathrm{p}>0.05$. The study illustrated that there was relation $(\mathrm{P}>0.05)$ and the strength of relation was 0.306 . Statistical analysis between education level and keeping adequate water nearby stalls (Chi-square 8.363, $\mathrm{p}<0.05$ ) explored of the respondents was significant. Significant relationships between working experience and yearly income, cleaning stalls/cages daily, using same vehicles to transport poultry and humans, annual health check of the respondents, if the workers became infected whether reported to it public health authority and keeping adequate water nearby stalls illustrated (Chi-square 20.326, $\mathrm{p}<0.05$; Chi-square 24.147, $\mathrm{p}<0.05$; Chi-square 12.317, $\mathrm{p}<0.05$; Chisquare 14.223, $\mathrm{p}<0.05$; Chi-square 21.538, $\mathrm{p}<0.05$ and Chi-square 10.494, $\mathrm{p}<0.05$ ) that working experience was moderately significant with yearly income, highly significant with cleaning stalls/cages daily, significant with using same vehicles to transport poultry and humans, highly significant with annual health check of the respondents, if the workers became infected whether reported to it public health authority and keeping adequate water nearby stalls, respectively. Significant relationships between location of business and using same vehicles to transport poultry and humans, if the workers became infected whether reported to it public health authority and keeping adequate water nearby stalls showed (Chi-square 12.813, $\mathrm{p}<0.05$; Chi-square $5.900, p>0.05$ and Chi-square $10.843, p<0.05$ ) that location of business was highly significant, not significant and highly significant, respectively [Table 1].

Table 1. Statistical analysis of education level, working experience and location of business with variables from urban and rural poultry workers

\begin{tabular}{|c|c|c|}
\hline Cross tab events & $\begin{array}{c}\text { Pearson } \\
\text { Chi-Square Value }\end{array}$ & $\begin{array}{c}\text { P-value } \\
\text { (approx. sig.) }\end{array}$ \\
\hline Education level vs. Waste management from poultry business & 20.228 & 0.063 \\
\hline Education level vs. Keeping adequate water nearby stalls & 8.363 & 0.039 \\
\hline Working experience vs. Yearly income & 20.326 & 0.026 \\
\hline Working experience vs. Cleaning stalls/cages daily & 24.147 & 0.000 \\
\hline Working experience vs. using vehicles to transport poultry and humans & 12.317 & 0.015 \\
\hline Working experience vs. Annual health check of the respondents & 14.223 & 0.007 \\
\hline $\begin{array}{l}\text { Working experience vs. If workers became infected whether reported to it Public health } \\
\text { authority }\end{array}$ & 21.538 & 0.000 \\
\hline Working experience vs. Keeping adequate water nearby stalls & 10.494 & 0.005 \\
\hline Location of business vs. Using same vehicles to transport poultry and humans & 12.813 & 0.002 \\
\hline $\begin{array}{l}\text { Location of business vs. If the workers became infected whether reported to it Public health } \\
\text { authority }\end{array}$ & 5.900 & 0.052 \\
\hline Location of business vs. Keeping adequate water nearby stalls & 10.843 & 0.002 \\
\hline
\end{tabular}

\subsection{Discussion}

\subsubsection{Discussion of general information of the workers of live bird market}

General information of the workers both in urban and rural live bird markets indicated that $22 \%$, $53 \%$, and $25 \%$ of urban and $19 \%, 64 \%$, and $14 \%$ of rural LBM workers were aged between 18 to 25 years, 25 to $<40$ years and $\geq 40$ years, respectively (average 35 years) and $100 \%$ of urban and $97 \%$ of rural respondents were male. Poultry Farmers' Utilization of Information in Lagelu Local Government Area, Oyo State of Nigeria research reported that an average age of the respondents was 37 years and $89 \%$ were male [21]. From the respondents $53 \%$ and $42 \%$ of urban and $50 \%$ and $31 \%$ of rural LBM workers were up to primary school and secondary school respectively. Highly pathogenic avian influenza knowledge, attitude and practices study on biosecurity of workers in live bird markets at Mymensingh, Bangladesh study revealed that about half the respondents had attended up to secondary school and below one-third were illiterate [5]; and knowledge, attitudes and compliance of poultry workers with preventive measures for avian influenza in Lagelu, Oyo State, Nigeria study explored that the majority (70\%) of respondents had attended at least a high school [7]. Among respondents $31 \%, 25 \%$, and $44 \%$ of urban workers and $45 \%, 44 \%$, and $11 \%$ of rural workers have experienced 1 to $<5$ years, 5 to $<10$ years and $\geq 10$ years, respectively. Highly pathogenic avian influenza knowledge, attitudes, and practices study among live bird market workers in Jakarta- Indonesia 
study reported that the workers' job experience was divided into 3 categories: $19 \%$ of the workers had job experience of $<5$ years, $48 \%$ had job experience of between 5 to $<10$ years, while $33 \%$ had job experience of $\geq 10$ years [6] [Table 2].

Significant relationships between education level of respondents and waste management from poultry business showed that there was relation $(\mathrm{P}>0.05)$ and the strength of relation was 0.306 . Statistical analysis between education and keeping adequate water nearby stalls (Chi-square 8.363, $\mathrm{p}<0.05)$ explored that education level of the respondents was significant [Table 1]. Poultry Farmers' Utilization of Information in Lagelu Local Government Area, Oyo State of Nigeria research reported that significant relationships between poultry farmer's sex, educational level and their sources of information (Chi-square $=0.13, p<0.05$ and Chi-square $=0.13, \mathrm{p}<0.05)$ [21]. Poultry Farmers' Access to Extension Services in Atisbo Local Government Area of Oyo State, Nigeria study explored that Chi-square test showed significant relationship between poultry farmers' access to extension services and farmers personal characteristics such as sex (Chisquare $=9.09, \mathrm{P}=0.00$ ), educational level (Chi-square $=16.79, \mathrm{P}=0.00)$ and membership of farmers' association (Chi-square $=15.33, \mathrm{P}=0.01)$ at 0.05 level of significance [18].

Table 2. General information of poultry workers of live bird market

\begin{tabular}{lcc}
\hline Indicators & Urban (\%) & Rural (\%) \\
\hline & Gender & \\
Male & $36(100)$ & $35(97)$ \\
Female & $(0)$ & $1(3)$ \\
& Age & \\
$<18$ & $0(0)$ & $1(3)$ \\
$18-25$ & $8(22)$ & $7(19)$ \\
$25-<40$ & $19(53)$ & $23(64)$ \\
$\geq 40$ & $9(25)$ & $5(14)$ \\
& Education level & $2(5)$ \\
Illiterate & $2(5)$ & $18(50)$ \\
Primary school & $19(53)$ & $11(31)$ \\
Secondary school & $15(42)$ & \\
Higher secondary and & & $5(14)$ \\
above & $0(0)$ & $0(0)$ \\
& Working experience & $16(45)$ \\
$<1$ year & $0(0)$ & $16(44)$ \\
$1-<5$ years & $11(31)$ & 4 \\
$5-<10$ years & $9(25)$ & $(11)$ \\
& & \\
$\geq 10$ years & $16(44)$ & \\
\hline
\end{tabular}

\subsubsection{Discussion of knowledge of the studied population about influenza}

All $(100 \%)$ of the LBM workers of both urban and rural areas had idea about HPAI. From the respondents $67 \%$ and $30 \%$ of urban and $47 \%$ and $50 \%$ of rural LBM workers answered that the causative agent of bird flu was virus and don't know, respectively. Highly pathogenic avian influenza knowledge, attitudes, and practices study among live bird market workers in Jakarta- Indonesia study reported that all $(100 \%)$ of the workers had heard about HPAI and only $23 \%$ of the workers knew the cause of HPAI, while $77 \%$ of the workers did not know or gave a wrong answer for the cause of HPAI [6]. The study indicated that $75 \%$ and $6 \%$ of urban workers and $42 \%$ and $28 \%$ of rural workers learnt about HPAI from media (TV, Radio etc) and veterinarian, respectively. Knowledge, attitudes and compliance of poultry workers with preventive measures for avian influenza in Lagelu, Oyo State, Nigeria study reported similarly that $74.3 \%$ workers answered mass media (television, radio and newspaper) as their main source of information [7] and Poultry Farmers Awareness and Knowledge of Improved Production Practices in Afijio, Local Government Area, Oyo State, Nigeria explored that radio (92.7\%) and Television (90.3\%) were the main source of the farmers' awareness on poultry production technique [19] . Based on waste management from poultry business, 3\%, $75 \%$, and $11 \%$ of urban workers and $14 \%, 72 \%$, and $6 \%$ of rural workers threw them away in the river/pond, in a specific pit for poultry waste and in the river/pond, respectively. Highly pathogenic avian influenza knowledge, attitudes, and practices study among live bird market workers in Jakarta- Indonesia study reported that sixty-three percent of the workers gave a wrong answer and $11 \%$ did not know what they should do with the waste products from their business. Only $26 \%$ of the workers knew what to do with the waste products from their business [6]. Eighty-nine percent, 5\% of urban workers and $69 \%, 11 \%$ of rural workers thought that avian influenza could be transmitted through contact with infected/sick poultry and contact with human infected with bird flu, respectively. Poultry Farmers' Utilization of Information in Lagelu Local Government Area, Oyo State of Nigeria research reported that $55 \%$ of the workers did not know and $48 \%$ of 
the workers knew how HPAI spreads to humans [21]. Twenty-eight percent, $61 \%$ of urban respondents and $6 \%, 58 \%$ of rural respondents told that the symptoms of bird flu in humans were fever and difficult/fast breathing respectively. Highly pathogenic avian influenza knowledge, attitudes, and practices study among live bird market workers in Jakarta- Indonesia study illustrated that $73 \%$ workers could describe and $27 \%$ of the workers could not describe symptoms of HPAI in humans, which is dissimilar to the findings of the present study [6]. Based on prevention technique of bird flu when handling live/dead poultry: $22 \%, 47 \%$, and $17 \%$ of urban workers; and $36 \%, 22 \%$, and $33 \%$ of rural workers told that they should wear gloves and wash hands afterwards respectively. Knowledge, attitudes and compliance of poultry workers with preventive measures for avian influenza in Lagelu, Oyo State, Nigeria study reported that the majority (81.4\%) reported always washing their hands and only $11.4 \%$ reported that they always used a facemask as preventive measure to protect the transmission of avian influenza [7] [Table 3].

Table 3. Knowledge about avian influenza of target population

\begin{tabular}{|c|c|c|c|}
\hline Question & Knowledge & Urban (\%) & Rural (\%) \\
\hline \multicolumn{4}{|c|}{ Idea about bird flu } \\
\hline & Yes & $36(100)$ & $36(100)$ \\
\hline & No & $0(0)$ & $0(0)$ \\
\hline \multicolumn{4}{|c|}{ Causative agent of bird flu } \\
\hline & Virus & $24(67)$ & $17(47)$ \\
\hline & Bacteria & $0(0)$ & $1(3)$ \\
\hline & Parasite & $1(3)$ & $0(0)$ \\
\hline & Don't know & $11(30)$ & $18(50)$ \\
\hline \multicolumn{4}{|c|}{ How to know about highly pathogenic avian influenza (HPAI) } \\
\hline & From other businessman & $3(8)$ & $6(16)$ \\
\hline & From purchaser & $2(5)$ & $4(11)$ \\
\hline & Media (TV, Radio etc.) & $27(75)$ & $15(42)$ \\
\hline & Self experience & $1(3)$ & $0(0)$ \\
\hline & From veterinarian & $2(6)$ & $10(28)$ \\
\hline & Other sources & $1(3)$ & $1(3)$ \\
\hline \multicolumn{4}{|c|}{ Waste management from poultry business } \\
\hline & Throw them away in the river/pond & $1(3)$ & $5(14)$ \\
\hline & Throw them in a specific pit for poultry waste & $27(75)$ & $26(72)$ \\
\hline & Throw them in a public dumpster & $4(11)$ & $2(6)$ \\
\hline & Burn them & $2(6)$ & $3(8)$ \\
\hline & Others & $2(6)$ & $0(0)$ \\
\hline \multicolumn{4}{|c|}{ Spreading bird flu bird flu in humans } \\
\hline & Contact with infected/sick poultry & $32(89)$ & $25(69)$ \\
\hline & Contact with other contaminated equipment & $0(0)$ & $3(8)$ \\
\hline & Eat raw/undercooked poultry products & $1(3)$ & $1(3)$ \\
\hline & Contact with human infected with bird flu & $2(5)$ & $4(11)$ \\
\hline & Others & $1(3)$ & $3(8)$ \\
\hline \multicolumn{4}{|c|}{ Symptoms of bird flu in humans } \\
\hline & Fever & $10(28)$ & $2(6)$ \\
\hline & Difficult/fast breathing & $22(61)$ & $21(58)$ \\
\hline & Cough & $0(0)$ & $0(0)$ \\
\hline & Sore throat & $1(3)$ & $0(0)$ \\
\hline & Eye infection & $1(3)$ & $0(0)$ \\
\hline & Others & $2(5)$ & $13(36)$ \\
\hline \multicolumn{4}{|c|}{ Prevention technique of bird flu when handling live/dead poultry } \\
\hline & Wear gloves & $8(22)$ & $13(36)$ \\
\hline & Wear a mask & $17(47)$ & $8(22)$ \\
\hline & Wash hands afterwards & $6(17)$ & $12(33)$ \\
\hline & Clean area afterwards & $3(8)$ & $2(6)$ \\
\hline & Others & $2(6)$ & $1(3)$ \\
\hline
\end{tabular}

\subsubsection{Discussion of attitude assessment about avian influenza of target population}

Among respondents $86 \%, 3 \%$, and $11 \%$ of urban residence and $81 \%, 5 \%$, and $14 \%$ of rural residence were satisfied, not satisfied and did not know respectively with the government efforts in controlling bird flu. Avian influenza viruses in Korean live poultry markets and their pathogenic potential research reported that $8 \%, 25 \%$, and $67 \%$ of the workers were satisfied, were not satisfied and were not sure or did not know about the government efforts in controlling HPAI, which was completely inconsistent to the present study [10]. Based on whether bird flu issues affect the sales, 14\%, 28\% and 58\% of urban and 14\%, $61 \%$, and $25 \%$ of rural were agreed, did not agreed and did not know respectively Avian influenza A (H5N1) infection in humans study indicated that $50 \%, 36 \%$ and $14 \%$ of the workers thought that HPAI issues did affect their sales, did not affect their sales and did not know [3]. Based on whether bird flu in poultry can be 
cured, $25 \%, 3 \%$, and $72 \%$ of urban respondents and $22 \%, 33 \%$, and $45 \%$ of rural respondents were agreed, did not agreed and did not know respectively. Avian Influenza as an emerging infection obtained that $74 \%$, $6 \%$, and $20 \%$ of the workers were not sure, were agreed and did not agreed respectively, which were almost consistent to the findings of present study [1]. From the respondents $44 \%$ and $56 \%$ of urban residence and $66 \%$ and $28 \%$ residence were agreed and did not know that people can get bird flu by touching sick poultry. Highly pathogenic avian influenza knowledge, attitudes, and practices study among live bird market workers in Jakarta- Indonesia study reported that $83 \%$ of the workers did not agree and only $17 \%$ of the workers did agree that people can get HPAI by touching infected poultry; which was not similar to the present study [6]. Relating to the question on human bird flu can be associated with the environment in the wet markets, $8 \%$, $36 \%$, and $56 \%$ of urban workers and $16 \%, 42 \%$, and $42 \%$ of rural workers did not agree, agreed and did not know respectively. Avian influenza risk perception, Hong Kong research explored that $81 \%$ workers were not sure or did not agree that human HPAI can be associated with the environment in wet markets, while $19 \%$ workers did not agree. So these findings were not corresponding to the results of the present study [9]. Relating to the question on bird flu is a serious disease because it can cause death in humans, $94 \%$ and $6 \%$ of urban workers and $92 \%$ and $3 \%$ of rural workers were agreed and did not know respectively, while only $5.55 \%$ of rural workers did not agreed to it. Towards control of avian influenza H5N1 virus in Indonesia: Human infection and the role of live bird markets study reported that $95 \%, 3 \%$, and $2 \%$ of the workers did agree, did not agree and were not sure or did not know that HPAI is a harmful disease because it can cause death in humans, which were completely consistent to the findings of the present study [11] [Table 4].

Table 4. Attitude assessment about avian influenza of target population

\begin{tabular}{|c|c|c|c|}
\hline Question & Attitudes & Urban $(\%)$ & Rural (\%) \\
\hline \multicolumn{4}{|c|}{ Satisfaction with the government efforts in controlling bid flu } \\
\hline Satisfied & & $31(86)$ & $29(81)$ \\
\hline Not satisfied & & $1(3)$ & $2(5)$ \\
\hline Do not know & & $4(11)$ & $5(14)$ \\
\hline \multicolumn{4}{|l|}{ Bird flu issues affect my sales } \\
\hline Agree & & $5(14)$ & $5(14)$ \\
\hline Do not agree & & $10(28)$ & $22(61)$ \\
\hline Do not know & & $21(58)$ & $9(25)$ \\
\hline \multicolumn{4}{|l|}{ Bird flu in poultry can be cured } \\
\hline Agree & & $9(25)$ & $8(22)$ \\
\hline Do not agree & & $1(3)$ & $12(33)$ \\
\hline Do not know & & $26(72)$ & $16(45)$ \\
\hline \multicolumn{4}{|c|}{ People can get bird flu by touching sick poultry } \\
\hline Agree & & $16(44)$ & $24(66)$ \\
\hline Do not agree & & $0(0)$ & $2(6)$ \\
\hline Do not know & & $20(56)$ & $10(28)$ \\
\hline \multicolumn{4}{|c|}{ Human bird flu can be associated with the environment in the wet markets } \\
\hline Agree & & $13(36)$ & $15(42)$ \\
\hline Do not agree & & $3(8)$ & $6(16)$ \\
\hline Do not know & & $20(56)$ & $15(42)$ \\
\hline \multicolumn{4}{|c|}{ Bird flu is a serious disease because it can cause death in humans } \\
\hline Agree & & $34(94)$ & $33(92)$ \\
\hline Do not agree & & (0) 0 & $2(5)$ \\
\hline Do not know & & $2(6)$ & $1(3)$ \\
\hline
\end{tabular}

\subsubsection{Practice assessment about avian influenza of target population}

Practice assessment study has revealed, $33 \%, 45 \%$, and $22 \%$ of urban workers and $17 \%, 50 \%$, and $33 \%$ of rural workers used proper personal protective equipment (PPE) as mask, gloves, etc. all the time, sometimes and never respectively when handling live birds, feces, feathers, or bedding, or while slaughtering the birds. Highly pathogenic avian influenza knowledge, attitudes, and practices study among live bird market workers in Jakarta, Indonesia study reported that $83 \%$ of the workers never used proper PPE and only $17 \%$ of the workers sometimes used proper PPE; which was not similar to the present study [6]. Among respondents $56 \%, 25 \%$, and $19 \%$ of urban residence and $36 \%, 36 \%$, and $28 \%$ of rural residence cleaned the stalls or cages daily by using disinfectant or water all the times, sometimes and never respectively and mostly they used water as cleaning material. Knowledge, attitudes and compliance of poultry workers with preventive measures for avian influenza in Lagelu, Oyo State, Nigeria survey was conducted where the majority $(81.4 \%)$ reported always cleaned the stalls or cages daily [7]. From the study $81 \%$ and $14 \%$ of urban workers and $89 \%$ and $11 \%$ of rural workers washed their hands and equipment every time after finishing work all the times and sometimes, respectively, while only $5 \%$ of urban workers never washed their hands and equipment after finishing work. After the outbreak: how the British Columbia commercial poultry 
industry recovered after H7N3 HPAI study explored that all of the workers washed their hands and equipment every time after finishing work and all of the workers used soap or disinfectant every time to clean their hands and equipment [16]. Twenty-eight percent, $53 \%$ and $19 \%$ of urban workers and $28 \%, 39 \%$, and $33 \%$ of rural workers spray disinfectant on vehicles before and after they are used to transport poultry all the times, sometimes and never respectively. Attitudes: Their structure, function and consequences study revealed that $93 \%$ of the workers always sprayed disinfectant on their vehicles before and after transporting poultry, which were completely inconsistent to the findings of the present study [20]. Seventy-two percent of urban workers and $31 \%$ of rural workers never used the same vehicle to transport chickens and other poultry. Cleaning and Disinfection of Poultry Farms study revealed that $92 \%$ of the workers always used the same vehicle to transport chicken and other poultry, while $8 \%$ never used the same vehicle indicating that these results were almost opposite to the present findings [12]. Fourteen percent and $78 \%$ of urban workers and $36 \%$ and $64 \%$ of rural workers used the same vehicle to transport poultry and humans all the times and never respectively. Highly pathogenic avian influenza knowledge, attitudes, and practices study among live bird market workers in Jakarta, Indonesia study reported that $93 \%$ of the workers never used the same vehicle to transport poultry and humans, which are inconsistent to the findings of the present study [6] [Table 5]. Statistical analysis between working experience and cleaning the stalls or cages: Chi-square was 24.147, $\mathrm{P}<0.01$, which was highly significant. Significant relationships between working experience and using same vehicles to transport poultry and humans: Chi-square was 12.317 , P-value 0.015 ; location of business and using same vehicles for poultry and humans: Chi-square was 12.813 , P-value 0.002 . So that in both cases $0.05>\mathrm{P}<0.01$, location of business was significant and highly significant [Table 1].

Table 5. Poultry workers' response to practice related question towards avian influenza and biosecurity

\begin{tabular}{|c|c|c|c|}
\hline Practices & Answers & Urban $(\%)$ & Rural (\%) \\
\hline \multirow{3}{*}{$\begin{array}{l}\text { Using proper PPE when handling live birds, feces, feathers, } \\
\text { or bedding, or when slaughtering the birds }\end{array}$} & All the times & $12(33)$ & $6(17)$ \\
\hline & Sometimes & $16(45)$ & $18(50)$ \\
\hline & Never & $8(22)$ & $12(33)$ \\
\hline \multirow{3}{*}{$\begin{array}{l}\text { Cleaning the stalls or cages daily by using disinfectant or } \\
\text { water }\end{array}$} & All the times & $20(56)$ & $13(36)$ \\
\hline & Sometimes & $9(25)$ & $13(36)$ \\
\hline & Never & $7(19)$ & $10(28)$ \\
\hline \multirow[t]{3}{*}{ Washing hands and any equipment when work is finished } & All the times & $29(81)$ & $32(89)$ \\
\hline & Sometimes & $5(14)$ & $4(11)$ \\
\hline & Never & $2(5)$ & $0(0)$ \\
\hline \multirow{3}{*}{$\begin{array}{l}\text { Spraying disinfectant on vehicles before and after they are } \\
\text { used to transport poultry }\end{array}$} & All the times & $10(28)$ & $10(28)$ \\
\hline & Sometimes & $19(53)$ & $14(39)$ \\
\hline & Never & $7(19)$ & $12(33)$ \\
\hline \multirow{3}{*}{$\begin{array}{l}\text { Using the same vehicle to transport chickens and other } \\
\text { poultry }\end{array}$} & All the times & $5(14)$ & $11(31)$ \\
\hline & Sometimes & $5(14)$ & $14(38)$ \\
\hline & Never & $26(72)$ & $11(31)$ \\
\hline \multirow[t]{3}{*}{ Using the same vehicle to transport poultry and humans } & All the times & $5(14)$ & $13(36)$ \\
\hline & Sometimes & $3(8)$ & $0(0)$ \\
\hline & Never & $28(78)$ & $23(64)$ \\
\hline
\end{tabular}

Regarding barriers, when poultry workers were asked about why some people refuse to wash their hands and equipment with soap/disinfectant before and after handling poultry, $92 \%$ of urban and $89 \%$ of the rural LBM workers thought it was because it is too much trouble, while 3\% of both the urban and rural workers thought it was because they were not aware of this recommendation. Hong Kong under WHO spot light after flu outbreak study illustrated that $6 \%$ thought it was because it is too much trouble, while $87 \%$ thought that it was because they were not aware of this recommendation [14].

\section{CONCLUSION}

Effective and coordinated information about avian influenza and taking the necessary precautions are essential. Data shows that about one-third to half of the poultry workers of LBM is unaware and do not have knowledge and practice related understanding. The lapse and gaps have been identified about the knowledge and preventive practices among poultry workers of LBM and to reduce and avoid spreading the avian influenza virus among poultry and humans. An outbreak of avian influenza in poultry as well as in humans may occur at any time. The compliance with preventive measures may be enhanced through behavioral change and building awareness through communication programs to the live bird market workers by the government and non-government organizations. The people of Keshabpur, Jessore, Bangladesh are at high risk of avian influenza and it is not known when and how the avian influenza viruses will re-enter our 
country. So, the thorough, on-going, systemic disease surveillance and prevention and awareness development programs should persistently be applied.

\section{ACKNOWLEDGEMENTS}

The authors would like to express deepest sense of gratitude to the staffs of upazila Livestock Office, Keshabpur upazila, Jessore for their cordial cooperation during data collection and also to those poultry workers of LBM, who provided information at the time of interviewing.

\section{REFERENCES}

[1] Ergin, S., "Avian Influenza as an emerging infection”, Veteriner-Fakultesi-Dergisi-Istanbul, vol./issue: 32(1), pp. 1-11, 2006.

[2] Ashraful-Kabir, M., "Avian influenza pandemics in Bangladesh”, Merit Research Journal, vol/issue: 1(1), pp. 001004, 2013.

[3] WHO, "Avian influenza A (H5N1) infection in humans", New England Journal of Medicine, vol. 353, pp. 137485, 2005.

[4] Ameji, ON., Abdu, PA., Sai'du, L., Kabir, J., Assam, A., “Awareness, Knowledge, Readiness to Report Outbreak and Biosecuritry Practices Towards Highly Pathogenic Avian Influenza in Kogi State, Nigeria", International Journal of Poultry Science, vol/issue: 5(1), pp.11-15, 2012.

[5] Sarker, S., Talukder, S., Haque-Chowdhury, E., Mohan-Das, P., "Highly pathogenic avian influenza knowledge, attitude and practices study on biosecurity of workers in Live bird markets at Mymensingh, Bangladesh", ARPN Journal of Agricultural and Biological Science, vol/issue: 6(2), pp. 12-17, 2011.

[6] Cahyadi-Sutanto, Y., "Highly pathogenic avian influenza knowledge, attitudes, and practices study among live bird market workers in Jakarta- Indonesia", Department of Clinical Sciences, Colorado State University, Fort Collins, Colorado. pp. 142+XI, Spring 2013. (Unpublished Thesis).

[7] Akinola, AF., Mobolaji MS., "Knowledge, attitudes and compliance of poultry workers with preventive measures for avian influenza in Lagelu, Oyo State, Nigeria", Journal of Infection in Developing Countries, vol/issue: 2(2), pp. 130-134, 2008.

[8] Sims, LD., Domenech, J., Benigno, C., Kahn, S., Kamata, A., Lubroth, J., et al., "Origin and evolution of highly pathogenic H5N1 avian influenza in Asia", Vet. Rec, vol. 157, pp. 159-164, 2005.

[9] Fielding, R., Lam, WW., Ho, EY., Lam, TH., Hedley, AJ., Leung, GM., "Avian influenza risk perception, Hong Kong", Emerging Infectious Diseases, vol/issue 11(5), pp. 677-82, 2005.

[10] Ki-Choi, Y., Heui-Seo, S., Kim, JA., Webby, RJ., Webster, RG., "Avian influenza viruses in Korean live poultry markets and their pathogenic potential", Virology, vol. 332, pp. 529-537, 2005.

[11] Samaan, G., "Towards control of avian influenza H5N1 virus in Indonesia: Human infection, and the role of live bird markets", The Australian National University, pp. 141+X, December 2011. (Unpublished Thesis).

[12] FAO, "Cleaning and Disinfection of Poultry Farms", 2011. Available at: URL:http://www.fao.org/docrep/014/al876e/al87600.pdf

[13] Audi, R., "Epistemology: A contemporary introduction to the theory of knowledge", $3{ }^{\text {rd }}$ edition, New York: Route ledge, 2011.

[14] Parry, J., "Hong Kong under WHO spot light after flu out break", British Medical Journal, vol. 327, pp. $308,2003$.

[15] WHO, "Cumulative Number of Confirmed Human Cases of Avian Influenza A/(H5N1) Reported to WHO", 27 November 2009. Available at: URL: http://www.who.int/csr/disease/avian influenza/country/casestable200911/en

[16] Bowes, VA., "After the outbreak: how the British Columbia commercial poultry industry recovered after H7N3 HPAI”, Avian Dis, vol. 51, pp. 313-316, 2007.

[17] Roy, P., Islam, SMR., Rahman, F., Siddiqui, MMR., “Avian Influenza and Human Health”, AKMMC J, vol/issue: 5(1), pp. 35-38, 2014.

[18] Umunna, MO., Adeeko, A., Onifade, OT., Adigun, OS., Apapa, ON., "Poultry Farmers' Access to Extension Services in Atisbo Local Government Area of Oyo State, Nigeria", African Journal of Basic \& Applied Sciences, vol/issue: 4(6), pp. 221-225, 2012.

[19] Oyeyinka, RA., Raheem, WK., Ayanda, IF., Abiona, BG., "Poultry Farmers Awareness and Knowledge of Improved Production Practices in Afijio, Local Government Area, Oyo State, Nigeria", International Journal of Agricultural Economics \& Rural Development, vol/issue: 5(1), pp. 74-82, 2012.

[20] Petty, RE., Fazio, RH., "Attitudes: Their structure, function and consequences", Psychology Press, New York, 2008.

[21] Pipy-Fawole, O., "Poultry Farmers' Utilization of Information in Lagelu Local Government Area, Oyo State of Nigeria”, International Journal of poultry science, vol/issue: 5(5), pp. 499-501, 2006. 


\section{BIOGRAPHIES OF AUTHORS}
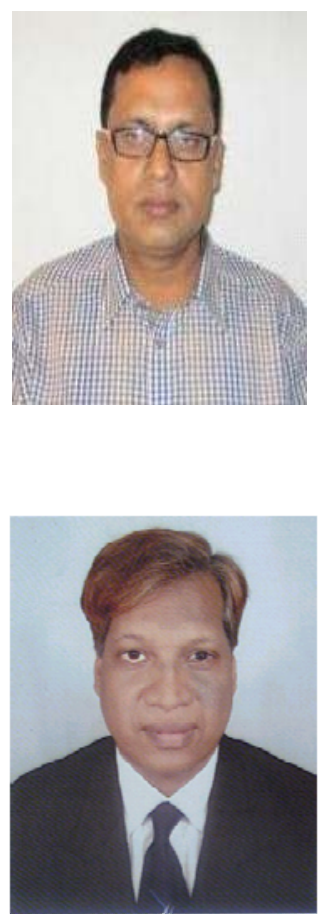

Swapan Kumar Roy, a student of MPH, Department of Public Health, Northern University Bangladesh. I have just completed the course defending the thesis paper in front of the Examination Board on September 27, 2014. I completed my graduation DVM from Bangladesh Agricultural University, Mymensingh, Bangladesh. A registered veterinarian in Bangladesh and very much interested in research. I am a government service holder and working as Upazila Livestock Officer at Keshabpur Upazila, Jessore, Bangladesh. I have taken initiative to enhance knowledge and change behavior of people most at risk and precautions necessary to avoid spreading the avian influenza virus among poultry and humans. I wish to work in livestock management as well as environmental safeguard relating to the public health.

Quazi Zahangir Hossain, the Professor of Environmental Science Discipline, Khulna University as well as Adjunct Faculty, Department of Public Health, Northern University Bangladesh, Khulna Campus and a member of different learned bodies. Teaching and research have contributed to write books and about 30 research articles jointly with other researcher which has been published to different international and national journals. Currently supervising two PhD students. Recently become interested in health related issues and being involved in research and consultation. 